Dear Author,

Please, note that changes made to the HTML content will be added to the article before publication, but are not reflected in this PDF.

Note also that this file should not be used for submitting corrections. 


\title{
Q1 Origin matters - Comparative transcriptomics in Saccharina latissima (Phaeophyceae)
}

\author{
Q2 Sandra Heinrich ${ }^{\mathrm{a}, \mathrm{b}, *}$, Klaus Valentin ${ }^{\mathrm{b}}$, Stephan Frickenhaus ${ }^{\mathrm{b}, \mathrm{c}}$, Christian Wiencke \\ a University of Hamburg, Ohnhorst Str.18, 22609 Hamburg, Germany \\ ${ }^{\mathrm{b}}$ Alfred Wegener Institute Helmholtz Centre for Polar and Marine Research, Am Handelshafen 12, 27570 Bremerhaven, Germany \\ ${ }^{\mathrm{c}}$ Hochschule Bremerhaven, An der Karlstadt 8, 27568 Bremerhaven, Germany
}

.

\section{A R T I C L E I N F O}

\section{Article history:}

Received 9 April 2015

Received in revised form 1 December 2015

Accepted 11 December 2015

Available online $\mathrm{xxxx}$

\section{Keywords:}

Abiotic stress

Growth conditions

Interactive effects

Kelp

Saccharina latissima

Transcriptomics

\begin{abstract}
A B S T R A C T
Kelps, brown algae of the order Laminariales, dominate rocky shores of cold-temperate regions and constitute im- 15 portant components of coastal ecosystems. Factors influencing their distribution are light including UV-radiation, 16 and temperature, therefore future global environmental changes will likely have an impact on their zonation, dis- 17 tribution patterns, and primary productivity. Here the question was addressed whether laboratory studies can 18 allow such predictions on natural communities by exploring interactive effects of UV-radiation, temperature 19 and growth conditions, on cultivated versus field sporophytes of Saccharina latissima. Both were exposed for 20 $24 \mathrm{~h}$ to UV-radiation at three different temperatures $\left(2,7 \& 12{ }^{\circ} \mathrm{C}\right)$, gene expression profiles under UV- 21 radiation at different temperatures were assessed through microarray hybridizations, and comparisons of gene 22 expression profiles in field versus culture sporophytes were carried out. Principal effects of UV-radiation were 23 similar in culture and field sporophytes, demonstrating laboratory experiments being well suited for investigat- 24 ing basic molecular mechanisms of acclimation to abiotic stresses in the field. However, sporophytes from the 25 field reacted less intense than laboratory cultures, indicating that the severity of transcriptomic responses in 26 situ may be over-estimated from laboratory experiments.
\end{abstract}

c) 2015 Published by Elsevier B.V. 28

\section{0}

38

\section{Introduction}

Global environmental changes, e.g. global warming and increased UV-radiation (UVR) represent major threats to polar marine ecosystems (Bartsch et al., 2012; Bischof et al., 2006; Harley et al., 2006). According to the Fourth Assessment Report of the United Nations Intergovernmental Panel on Climate Change a global average surface warming in the range of $2.4-6.4^{\circ} \mathrm{C}$ is predicted by 2100 . The warming is expected to be strongest at high northern latitudes and least in the Antarctic region (IPCC, 2007). Since 1950 mean annual sea surface temperatures in the North Atlantic have risen by more than $1.5^{\circ} \mathrm{C}$, which is more than twice of the global average (Merzouk and Johnson, 2011). Recent depletion of the stratospheric ozone layer has caused enhanced UVR at the surface, especially pronounced at high latitudes (Kerr and McElroy, 1993; Madronich et al., 1998). Also, an unprecedented ozone loss has been demonstrated over the Arctic (Manney et al., 2011). At the worst case future scenario an ozone depletion over the Arctic up to $20 \%$ until 2020 is forecasted (WMO, 2006).

There is consensus that coastal marine ecosystems in general are endangered by global climate changes (Helmuth et al., 2006; IPCC, 2001).

\footnotetext{
* Corresponding author at: University of Hamburg, Ohnhorst Str.18, 22609 Hamburg, Germany.

E-mail address: Sandra.Heinrich@awi.de (S. Heinrich).
}

Benthic macroalgae constitute important components of marine coastal 59 ecosystems in providing food for herbivores and detritivores, as well as 60 a habitat for many sessile and motile organisms (Carlsen et al., 2007; 61 Lippert et al., 2001; Lüning, 1990). In addition macroalgae account for 62 up to $10 \%$ of the global oceanic primary production (Carlsen et al., 63 2007; Charpy-Roubaud and Sournia, 1990; Lüning, 1990; Smith, 1981; 64 van de Poll et al., 2003). Primary abiotic factors determining vertical 65 zonation and geographical distribution of macroalgae are temperature 66 and light, including UVR (Bartsch et al., 2008; Hanelt, 1998; Wiencke 67 et al., 2006). It is thus likely that the increase of UVR and sea surface 68 temperatures will influence distribution patterns of benthic 69 macroalgae. Latitudinal shifts in species distribution of macroalgae as 70 ecological responses to climate changes have already been observed 71 (Hawkins et al., 2009; Lima et al., 2007; Simkanin et al., 2005). 72

UVR affects negatively photosynthesis in macroalgae, e.g. leading to 73 degradation of light harvesting complex proteins, D1/D2 heterodimer of 74 photosystem II, and influence secondary photosynthetic reactions 75 (Bischof et al., 2000, 2002a, 1998; Davison et al., 2007; Franklin et al., 76 2003). Another target of UVR in macroalgae is DNA (Britt, 1999; Hall 77 et al., 1992; Sinha and Häder, 2002). Studies demonstrated that expo- 78 sure to UVR leads to formation of cyclobutane-pyrimidine dimers 79 (CPDs), which can be removed by photoreactivation and nucleotide ex- 80 cision repair (Pakker et al., 2000a; van De Poll et al., 2002). UVR suscep- 81 tibility of macroalgae also seems to be life-stage dependent and is 82 
related to their vertical distribution (Roleda et al., 2006, 2007; Wiencke et al., 2007).

While damaging effects of elevated temperatures and UVR on seaweed physiology are well studied in single factor laboratory experiments only few projects focused on interactive effects and even less effects on field grown material. Simultaneous exposure to several stress factors can elevate their damaging effects, and might lead to an increase of susceptibility to additional stresses (Alexieva et al., 2003; Wernberg et al., 2010). Previous studies e.g. demonstrated interactive effects of temperature and UVR on germination of macroalgae (Hoffman et al., 2003; Müller et al., 2008). For some macroalgal species it was shown that photosynthetic efficiency under UVR was higher at moderate temperatures compared to low temperatures (Fredersdorf et al., 2009; Rautenberger and Bischof, 2006). These results underline the importance of multifactorial experiments, especially for investigating climate change effects. A perhaps even more important question is to what extent results obtained in the laboratory can be used to predict environmental effects in the field. Until now only few comparative studies of acclimation in laboratory and field grown macroalgae have been published, demonstrating no significant differences in physiological parameters (Bischof et al., 1999; Sagert and Schubert, 2000). Furthermore in our earlier transcriptomic studies in laboratory grown kelp we observed that treatments not causing measurable physiological reactions are yet visible in the transcriptome response to a large extent (Heinrich et al., 2012b, 2015). Such molecular response comes along with metabolic costs, which in the long run might influence growth, defense against pathogens, and further performance parameters.

Based on these findings we hypothesize that no differential physiological effects will be visible, but on the transcriptional level differences related to the origin of the sporophytes may be expected. We studied interactive effects of UVR and temperature on gene expression in Saccharina latissima freshly sampled in the field (Spitsbergen, Norway) versus established laboratory cultures. To prevent from population specific acclimation responses, field grown material was sampled from the same population as the established gametophytes stock cultures of S. latissima. The perennial kelp S. latissima is a common species in kelp beds of Arctic and cold-temperate coastal waters (Bolton et al., 1983; Borum et al., 2002; Gerard, 1988).

\section{Material \& methods}

\subsection{Algal material}

\subsubsection{Field grown material}

Sporophytes of S. latissima with a size of 5-7 $\mathrm{cm}$ were collected in May 2009 directly after the sea-ice breakup by scuba diving from $8 \mathrm{~m}$ water depths in Kongsfjorden (N 78 55.817'; E 011 ${ }^{\circ} 55.236^{\prime}$; Svalbard, Norway). The water temperature at that time was $1{ }^{\circ} \mathrm{C}$. Algae were transported to the laboratory in black plastic containers, were cleaned from epiphytes, and kept for $48 \mathrm{~h}$ in running seawater at $3-5^{\circ} \mathrm{C}$ under low light $\left(10 \mu \mathrm{mol}\right.$ photons $\left.\mathrm{m}^{-2} \mathrm{~s}^{-1}\right)$ prior to the exposure experiments.

\subsubsection{Culture material}

Unialgal cultures of gametophytes of S. latissima, originally established in 1991 from spores of fertile sporophytes collected by SCUBA diving in Kongsfjorden (N 78 55.817'; E 011 ${ }^{\circ} 55.236^{\prime}$; Svalbard, Norway, AWI culture numbers: 3123,3124 ) were used to raise young sporophytes. Filaments of male and female gametophytes were fragmented together, transferred to Petri dishes filled with Provasoli enriched seawater (PES) (Starr and Zeikus, 1993) and cultivated at $10 \pm 1^{\circ} \mathrm{C}$ and $30 \mu \mathrm{mol}$ photons $\mathrm{m}^{-2} \mathrm{~s}^{-1}$ white light at $18 \mathrm{~h} \mathrm{light:6 \textrm {h }}$ dark period. Developing sporophytes were transferred after 2 weeks to aerated 51 culture bottles and grown in PES until they reached a size of $5-7 \mathrm{~cm}$.

\subsection{Light \& temperature treatments}

Irradiation experiments were conducted in environmentally con- 145 trolled rooms at 2,7 and $12{ }^{\circ} \mathrm{C} \pm 1{ }^{\circ} \mathrm{C}$. Young sporophytes from different 146 origin were exposed for $24 \mathrm{~h}$ to low photosynthetically active radiation 147 (PAR) $\left(23.6 \pm 3 \mu \mathrm{mol}\right.$ photons $\left.\mathrm{m}^{2} \mathrm{~s}^{-1}\right)$ in combination with UVR (UV- 148 A: $10.56 \pm 1.04 \mathrm{~W} \mathrm{~m}^{-2}$; UV-B: $0.45 \pm 0.02 \mathrm{~W} \mathrm{~m}^{-2}$ ). Every experiment 149 was conducted in 5 replicates. For distinguishing the effects of different 150 wavelength ranges, the experimental units were covered with cut-off 151 filter foils transparent to wavelengths of: (1) 400-700 nm (URUV 152 Ultraphan UV farblos, Difrega, München, Germany) for PAR treatments, 153 and (2) 295-700 nm (URT 140 Ultraphan UV farblos, Difrega; München, 154 Germany) for PAR + UVA + UVB treatments. PAR was provided by 3/5 155 Osram daylight fluorescent tubes (Biolux, 36 W; Osram, München, 156 Germany) and measured by using a LI-250 light meter (LI-COR, 157 Lincoln; USA). UVR was generated by 3 fluorescent tubes (UV A-340, 158 40 W; Q-Panel, Homestead, USA) and determined with a Solar Light 159 PMA-2100 (Solar Light; Glenside, USA).

\subsection{Fluorescence measurements}

161

Maximum quantum yield of PS II (Fv/Fm) was measured in the be- 162 ginning and at the end of the experiment with an Imaging PAM (Pulse 163 Amplitude Fluorometer, Walz, Effeltrich, Germany). PAM measure- 164 ments were conducted as described by Hanelt (1998). Prior to the mea- 165 surements sporophytes were dark-adapted for $5 \mathrm{~min}$. Subsequent to the 166 fluorescence measurements sporophytes were frozen in liquid nitrogen 167 and stored at $-80^{\circ} \mathrm{C}$ until RNA extraction. Results of the photosynthetic 168 measurements were statistically compared by analysis of variance 169 (ANOVA) with repeated measurements $(\mathrm{p}<0.01)$. Significant differ- 170 ences as well as interaction of means were compared with the post 171 hoc Tukey test (HSD, p < 0.01). Statistical analysis was performed 172 using SPSS software version 19 (IBM, Armonk, USA).

\subsection{RNA-extraction and -labeling}

174

Total RNA extractions from differently treated sporophytes were 175 performed as described previously by Heinrich et al. (2012b) consisting 176 of a CTAB extraction, followed by the use of a Qiagen RNA isolation kit. 177 Total RNA was labeled with the Agilent two-color Low Input Quick 178 Amp Labeling kit (Agilent Technologies, Waldbronn, Germany). For 179 the pooled control sample 700 ng RNA from every low PAR treatment 180 was mixed together prior to the labeling in equal molar concentrations. 181 Here two pooled control samples were established, consisting of either 182 RNA from laboratory-grown sporophytes or field grown sporophytes. 183 RNA from stress treatments was labeled by fluorescent complementary 184 RNA (cRNA) synthesis with cyanine-5-CTP, control sample RNA was la- 185 beled with cyanine-3-CTP. Agilent RNA Spike-In Mix (Agilent) was 186 added to $200 \mathrm{ng}$ of total RNA prior to the labeling. On account of the ex- 187 tensive length of 3'untranslated regions (UTRs) occurring in brown 188 algae, cDNA synthesis was performed using a blend of T7 nonamer 189 primer and T7 promoter primer in equal molarity. cRNA synthesis and 190 purification of labeled RNA was conducted following the two-color 191 Low Input Quick Amp Labeling kit protocol (Agilent). cRNA yield, as 192 well as dye incorporation rates of cyanine-3 and cyanine-5, was mea- 193 sured with a NanoDrop ND-100 spectrometer (PeqLab, Erlangen, 194 Germany).

\subsection{Microarray design and hybridization}

196

Agilent's eArray online application tool was used to design $6 \times 80 \mathrm{k} 197$ microarrays slides, containing 60 mer oligonucleotides probes created 198 from a S. latissima cDNA library, which was established from RNA sam- 199 pled under several light and temperature conditions (Heinrich et al., 200 2012a). The cDNA library sequence assembly was deposited at DDBJ/ 201 
EMBL/GenBank under the accession GBBA00000000 (http://www.ncbi. nlm.nih.gov/nuccore/GBBA00000000).

Overall 25,262 transcripts were represented on the microarray by 1 , 2 or 3 individual probes. Hybridizations for all experimental conditions were performed in 4 replicates.

Total RNA samples derived from the treatments were hybridized against the pooled control respective to their origin. The microarray hybridization procedure was carried out with 300 ng of cyanine- 3 and cyanine-5 labeled cRNA for $17 \mathrm{~h}$ at $65^{\circ} \mathrm{C}$. Control/control hybridization were performed, each component of the pooled control (LP $2^{\circ} \mathrm{C}, \mathrm{LP} 7{ }^{\circ} \mathrm{C}$ $\mathrm{LP} 12^{\circ} \mathrm{C}$ ) was hybridized against the pooled control to mitigate dye bias effects. Subsequently microarray disassembly and wash procedure followed as described by the manufacturer's instructions (Agilent). Microarrays were scanned with the Agilent G2565AA scanner. Raw data were processed with the Agilent Feature Extraction Software version 9.1.3.1 (FE); array quality was monitored using the Agilent QC Tool (v1.0) with the metric set GE2_QCMT_Feb07. Data normalization was performed with the Agilent Feature Extraction Software version 9.1.3.1 (FE), which applies a linear normalization correction and the LOWESS smoothing. The microarray design, raw data and normalized data as well as the detailed experimental design are MIAME compliant and deposited in a MIAME compliant database (ArrayExpress at EMBL-EBI; https://www.ebi.ac.uk/arrayexpress/; ID: E-MTAB-3074).

\subsection{Statistical analysis of microarray data}

Testing for differential expressed genes was conducted using the GeneSpring GX software platform version 11 (Agilent) with the implemented statistical tests: An ANOVA, followed by a post hoc test Tukey HSD with the Benjamini and Hochberg (1995) FDR correction was performed. Genes were considered to be differentially expressed when the FDR corrected p-values were less than 0.01 and calculated absolute fold changes between the control and the treatment was at least 2. Enrichment of GO annotations within the regulated genes of the various exposure treatments was assessed by gene set enrichment analysis, which was done using Blast2GO (Conesa et al., 2005). Blast2GO applies the Fisher's exact test including corrections for multiple testing. Overrepresented KEGG pathways were identified by KOBAS (http://kobas. cbi.pku.edu.cn/home.do) using a hypergeometric test and multiple testing corrected p of $<0.01$ (Benjamini and Hochberg, 1995).

\section{Results}

\subsection{Photosynthetic measurements}

Fv/Fm was similarly affected by temperature, light, as well as by interaction of light and temperature treatments, respectively in cultivated and field grown material (RM ANOVA within-subject effects: Temperature $\mathrm{F}_{(2,48)}=14.736, \mathrm{p}<0.001 ; \operatorname{light} \mathrm{F}_{(1,48)}=244.725, \mathrm{p}<0.001$;

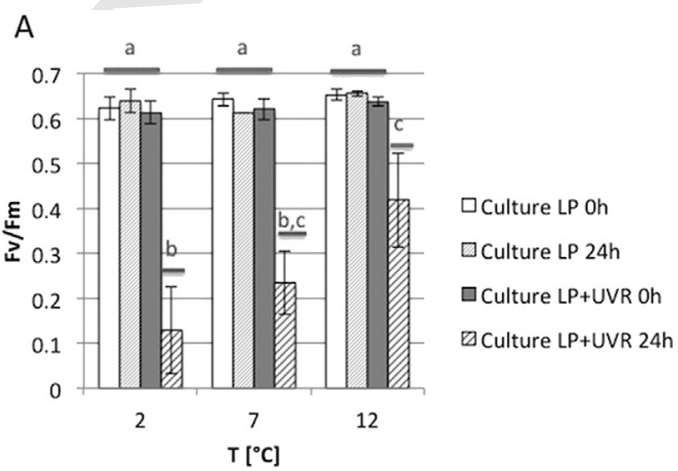

temperature $\times$ light $\left.\mathrm{F}_{(2,48)}=9.864, \mathrm{p}<0.001\right)$. Initial mean maximum 246 quantum yield $(\mathrm{Fv} / \mathrm{Fm})$ of laboratory grown sporophytes $(0.631 \pm 247$ $0.03)$ and field grown sporophytes $(0.637 \pm 0.03)$ remained unchanged 248 after exposure to low PAR at 2,7 , and $12{ }^{\circ} \mathrm{C}$ (Fig. 1). Exposure to low 249 PAR + UVR significantly reduced maximum quantum yield and reduc- 250 tion was significantly stronger $(\mathrm{p}<0.01)$ at $2{ }^{\circ} \mathrm{C}(\mathrm{Fv} / \mathrm{Fm}$ culture $=251$ $0.129 \pm 0.1 ; \mathrm{Fv} / \mathrm{Fm}$ field $=0.184 \pm 0.003)$ compared to $12^{\circ} \mathrm{C}(\mathrm{Fv} / \mathrm{Fm} 252$ culture $=0.418 \pm 0.104 ; \mathrm{Fv} / \mathrm{Fm}$ field $=0.39 \pm 0.177)$. In summary lab- 253 oratory and field grown material was not affected by temperature alone 254 but by UVR alone and the combinatory effects of UVR plus temperature, 255 whereby UVR was more harmful at lower temperatures. At the level of 256 $\mathrm{Fv} / \mathrm{Fm}$ sporophytes grown in the field could not be distinguished from 257 cultured samples.

\subsection{Microarray analysis}

Gene expression profiles under UVR stress at different temperatures 260 were obtained using oligonucleotide microarrays covering 25,262 tran- 261 scripts. Fewer regulated transcripts were detected in field grown versus 262 cultivated sporophytes in response to exposures (Fig. 2). In cultivated 263 S. latissima UVR caused a changed expression of 8166 transcripts 264 (32\%) in at least one stress treatment compared to the control treatment 265 $\left(2,7,12^{\circ} \mathrm{C} \&\right.$ low PAR). The strongest effect on gene expression in a sin- 266 gle treatment was observed after UVR exposure at $7{ }^{\circ} \mathrm{C}$ treatment when 267 3770 genes (15\%) were affected. Furthermore strong interactive effects 268 of temperature and UVR in laboratory grown sporophytes were ob- 269 served: at $12{ }^{\circ} \mathrm{C}$ the number of regulated genes was only half of that at 270 the $2{ }^{\circ} \mathrm{C}$ and $7{ }^{\circ} \mathrm{C}$ treatment.

In field grown material of S. latissima 1218 transcripts (5\%) showed 272 different expression patterns under at least one stress treatment com- 273 pared to the control treatment $\left(2,7,12{ }^{\circ} \mathrm{C}\right.$ \& low PAR), and highest num- 274 ber of regulated transcripts in a single treatment $(1014 \approx 4 \%)$ was 275 detected after the UVR treatment at $2{ }^{\circ} \mathrm{C}$.

For a more in depth comparison, the number of genes specifically 277 up-regulated in field grown and cultivated Saccharina, respectively, 278 were compared. Laboratory-grown sporophytes featured higher num- 279 bers of specifically regulated transcripts after all treatments (Table 1). 280 However, in both origins no functional differences in terms of molecular 281 processes were observed. A full list of specifically regulated transcripts 282 in cultivated and field material including annotations can be retrieved 283 from the supplemental material (Table S1).

\subsubsection{Gene Ontology term enrichments}

Gene Ontology (GO) term enrichments were applied to investigate 286 function of significantly up- and down-regulated transcripts in different 287 stress conditions. In cultivated sporophytes of S. latissima a total of 164288 over-represented GO terms were detected, the highest number was 289 found within the up-regulated genes after exposure to UVR at $2{ }^{\circ} \mathrm{C} 290$ (58, Table 2). In field grown sporophytes of S. latissima a total of 67291

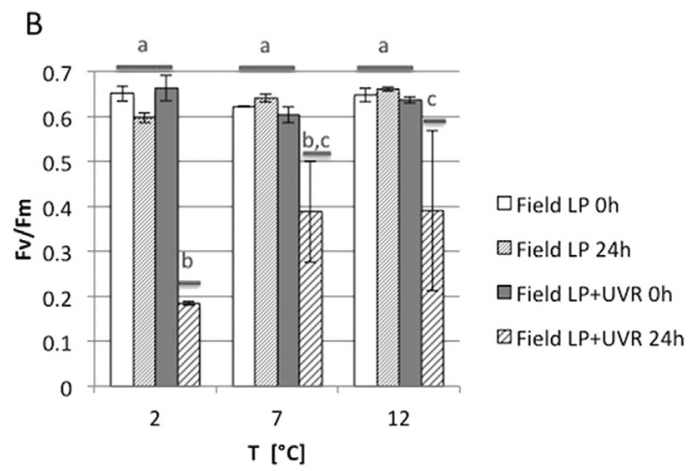

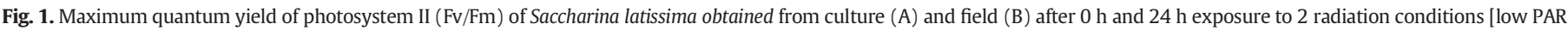

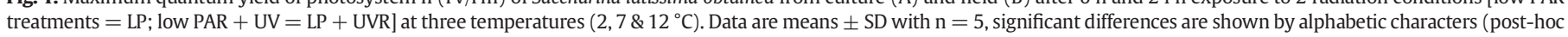
test Tukey HSD, $\mathrm{p}<0.01$ ). 


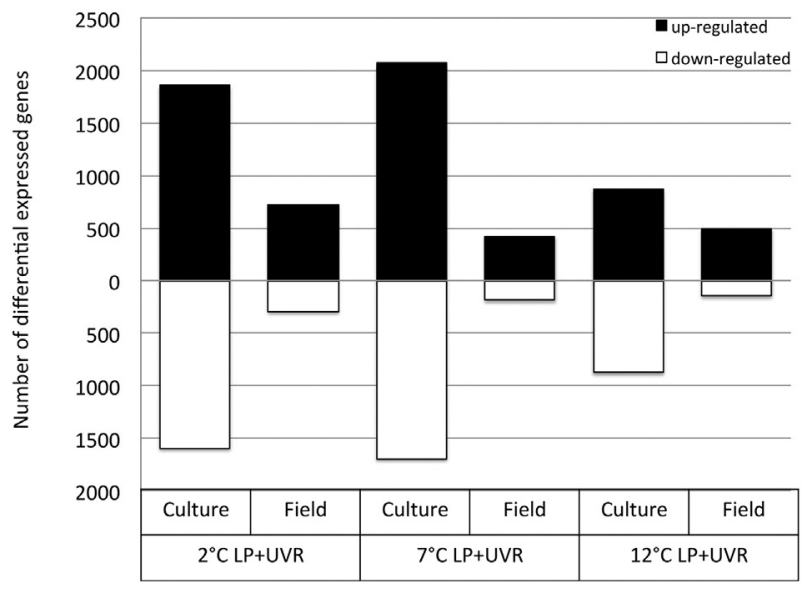

Fig. 2. Number of significantly different up- (black bars) and down-regulated (white bars) genes in Saccharina latissima from culture and field after exposure to low LP + UVR at 3 temperatures $\left(2,7 \& 12^{\circ} \mathrm{C}\right)$.

enriched GO terms was identified, with the highest number of overrepresented GO terms occurring after UVR exposure at $12{ }^{\circ} \mathrm{C}(25$, Table 1). Despite the large difference in the numbers of detected enriched GO terms in laboratory grown versus field grown material of S. latissima, similarity in terms of function was found. The majority of over-represented GO terms among the up-regulated transcripts of all UVR treatments were either correlated to photosynthetic components, DNA repair, or DNA replication in both sporophyte types. Cultivated sporophytes of $S$. latissima featured highest number of enriched GO terms related to nucleotides in response to UVR at $2{ }^{\circ} \mathrm{C}$ where 16 enriched terms were found; followed by the UVR conditions at $7{ }^{\circ} \mathrm{C}$ and $12{ }^{\circ} \mathrm{C}$, with respectively 11 and 4 over-represented GO terms. In field grown material of S. latissima 7 over-represented GO terms correlated to nucleotides occurred after UVR exposure at $7{ }^{\circ} \mathrm{C}$, whereas the UVR treatments at $2{ }^{\circ} \mathrm{C}$ and $12{ }^{\circ} \mathrm{C}$ featured accordingly 4 and 6 enriched GO terms. For a detailed list see Table S2.

Additional enriched GO terms were identified among the regulated transcripts in laboratory grown sporophytes versus field grown material. Induction of genes associated with vitamin metabolic processes and cellular anion homeostasis was observed after exposure to UVR at $2{ }^{\circ} \mathrm{C}$ and $7{ }^{\circ} \mathrm{C}$. These treatments furthermore caused repression of transcripts correlated to carbohydrate metabolic processes like glucan metabolic process and polysaccharide metabolic process.

\subsubsection{KEGG pathway analyses}

7 significantly enriched metabolic pathways were identified by KOBAS analysis within the UVR treatments at different temperatures

Table 1

Numbers of transcripts specifically regulated in cultivated versus field sporophytes of Saccharina latissima.

\begin{tabular}{|c|c|c|c|c|c|}
\hline \multirow[t]{2}{*}{ Origin } & \multirow[t]{2}{*}{ Treatments } & \multirow[t]{2}{*}{ Regulation } & \multicolumn{3}{|c|}{ Specifically regulated transcripts } \\
\hline & & & $\begin{array}{l}\text { Total } \\
\text { number }\end{array}$ & Annotated & $\begin{array}{l}\text { Unknown } \\
\text { function }\end{array}$ \\
\hline \multirow[t]{6}{*}{ Culture } & $2{ }^{\circ} \mathrm{C} L P+U V R$ & Up & 1499 & 499 & 1000 \\
\hline & $2^{\circ} \mathrm{C} \mathrm{LP}+\mathrm{UVR}$ & Down & 1492 & 480 & 1012 \\
\hline & $7{ }^{\circ} \mathrm{C} \mathrm{LP}+\mathrm{UVR}$ & Up & 1879 & 711 & 1168 \\
\hline & $7^{\circ} \mathrm{C} \mathrm{LP}+\mathrm{UVR}$ & Down & 1662 & 620 & 1042 \\
\hline & $12^{\circ} \mathrm{C} \mathrm{LP}+\mathrm{UVR}$ & Up & 688 & 271 & 417 \\
\hline & $12{ }^{\circ} \mathrm{C} \mathrm{LP}+\mathrm{UVR}$ & Down & 847 & 197 & 650 \\
\hline \multirow[t]{6}{*}{ Field } & $2{ }^{\circ} \mathrm{C} L P+U V R$ & Up & 58 & 27 & 31 \\
\hline & $2{ }^{\circ} \mathrm{C} \mathrm{LP} * \mathrm{UVR}$ & Down & 119 & 29 & 90 \\
\hline & $7^{\circ} \mathrm{C} \mathrm{LP}+\mathrm{UVR}$ & Up & 72 & 40 & 32 \\
\hline & $7^{\circ} \mathrm{C} \mathrm{LP}+\mathrm{UVR}$ & Down & 124 & 16 & 108 \\
\hline & $12^{\circ} \mathrm{C} \mathrm{LP}+\mathrm{UVR}$ & Up & 279 & 110 & 169 \\
\hline & $12^{\circ} \mathrm{C} \mathrm{LP}+\mathrm{UVR}$ & Down & 4 & 1 & 3 \\
\hline
\end{tabular}

(Table 3). Exposure of cultivated material to UVR at $2{ }^{\circ} \mathrm{C}$ led on the 318 one hand to up-regulation of transcripts involved in $\mathrm{ABC}$ transport 319 and glutathione metabolism, on the other hand to repression of alanine, 320 aspartate and glutamate metabolism, galactose metabolism, glycolysis/ 321 gluconeogenesis, as well as of the pentose phosphate pathway. Field 322 grown sporophytes under UVR at $2{ }^{\circ} \mathrm{C}$ and $7{ }^{\circ} \mathrm{C}$ increased expression 323 of carotenoid biosynthesis.

\subsubsection{Manual inspection of UVR-induced transcripts}

325

GO term enrichment analysis indicated induction of transcripts cor- 326 related to photosynthetic components, DNA repair, and vitamin $\mathrm{B}_{6}$ bio- 327 synthesis, therefore transcriptional changes of selected genes related to 328 these categories were manually analyzed on a gene per gene base 329 (Table 4). Furthermore the expression of reactive oxygen species 330 (ROS) scavenging enzymes was inspected (Table 3). A full list of the reg- 331 ulated genes with annotations can be retrieved from the supplemental 332 material (Table S3). Laboratory-grown sporophytes featured higher 333 number of regulated transcripts after UVR exposure than field grown 334 sporophytes, especially within the categories photosynthetic compo- 335 nents, DNA repair, and ROS scavenging enzymes. To investigate wheth- 336 er UVR not only influences the number of regulated genes, but also the 337 level of expression fold changes of individual genes, transcripts which 338 were simultaneously expressed in cultivated and field material were 339 compared.

3.2.3.1. Photosynthetic components. 9 transcripts encoding photosynthet- 341 ic components significantly regulated after exposure to UVR were ex- 342 amined. Transcripts of the cytochrome b6 complex (contig02465) 343 were induced in response to all treatments with transcriptional changes 344 between 2.2 and 3.2 fold, with the highest transcript fold change in 345 field grown sporophytes exposed to UVR at $12{ }^{\circ} \mathrm{C}$. Regulation of three 346 transcripts encoding for light harvesting proteins was observed, 347 Fucoxanthin-chlorophyll a-c binding protein (contig13579, in a BLAST 348 search most similar to the high-light LHCX clade) was significantly in- 349 duced in all treatments except after the $12{ }^{\circ} \mathrm{C}$ UVR treatment in cultures, 350 with the highest up-regulation of 253.9 fold occurring in field grown 351 material exposed to UVR at $2{ }^{\circ} \mathrm{C}$. Light harvesting complex protein 352 (contig24218) and light harvesting complex I $21 \mathrm{kDa}$ (contig08085) 353 were repressed in cultivated material at $2{ }^{\circ} \mathrm{C}$ and $7{ }^{\circ} \mathrm{C}$ UVR, in field 354 grown sporophytes after exposure to UVR at $2{ }^{\circ} \mathrm{C}$ light harvesting com- 355 plex I $21 \mathrm{kDa}$ was additionally down-regulated in field material in re- 356 sponse to UVR at $12{ }^{\circ} \mathrm{C}$. Photosystem I reaction centre subunit II 357 featured enhanced transcript abundances in field grown sporophytes 358 after all UVR conditions, in cultivated material only in response to UVR 359 at $7{ }^{\circ} \mathrm{C}$. Among genes correlated to photosystem II photosystem II D2 360 protein (contig03429) was induced in all treatments, photosystem II 361 biogenesis protein psp29 (contig02889), and photosystem II stability 362 assembly factor hcf136, (contig02680) were up-regulated after all treat- 363 ments except the culture $12{ }^{\circ} \mathrm{C}$ UVR treatment, respectively the field 364 $12{ }^{\circ} \mathrm{C}$ UVR treatment. Photosystem II protein (contig14092) showed 365 higher transcript abundance in cultivated material exposed to UVR at 366 $7{ }^{\circ} \mathrm{C}$, as well as in field grown material exposed to UVR at $2{ }^{\circ} \mathrm{C}$. 367

3.2.3.2. DNA repair. Several regulated transcripts associated with DNA 368 repair were identified. Rad51 DNA recombination repair protein 369 (contig07877) and X-ray repair cross-complementing protein 6370 (contig06170) were induced in all treatments except for cultivated ma- 371 terial subjected to UVR at $12^{\circ} \mathrm{C}$; here X-ray repair cross-complementing 372 protein 6 showed higher fold changes in field grown sporophytes than 373 in laboratory grown sporophytes. A deoxyribodipyrimidine photolyase 374 family protein (contig21643) was up-regulated in all treatments except 375 in laboratory grown material exposed to UVR at $12{ }^{\circ} \mathrm{C}$, highest fold 376 changes of these transcripts were detected in $2{ }^{\circ} \mathrm{C}$ UVR treatments of 377 both origins. Induction of DNA repair protein uvh3 (contig04132) was 378 observed in all treatments except in field grown material of the UVR 379 at $7{ }^{\circ} \mathrm{C}$ condition, highest transcript abundance in cultivated material 380 


\section{t2.1 Table 2}

t2.2 Numbers of over-represented Gene Ontology terms within the three GO root categories t2.3 cellular component, molecular function, and biological process among the different t2.4 treatments.

\begin{tabular}{|c|c|c|c|c|c|c|}
\hline $\mathrm{t} 2.5$ & \multirow[t]{2}{*}{ Origin } & \multirow[t]{2}{*}{ Treatments } & \multirow[t]{2}{*}{ Regulation } & \multicolumn{3}{|c|}{ GO root category } \\
\hline $\begin{array}{l}\mathrm{t} 2.6 \\
\mathrm{t} 2.7\end{array}$ & & & & $\begin{array}{l}\text { Cellular } \\
\text { component }\end{array}$ & $\begin{array}{l}\text { Molecular } \\
\text { function }\end{array}$ & $\begin{array}{l}\text { Biological } \\
\text { process }\end{array}$ \\
\hline $\mathrm{t} 2.8$ & Culture & $2{ }^{\circ} \mathrm{C} \mathrm{LP}+\mathrm{UVR}$ & Up & 18 & 27 & 13 \\
\hline $\mathrm{t} 2.9$ & & $2{ }^{\circ} \mathrm{C} \mathrm{LP}+\mathrm{UVR}$ & Down & - & 3 & 11 \\
\hline $\mathrm{t} 2.10$ & & $7^{\circ} \mathrm{C} \mathrm{LP}+$ UVR & Up & 18 & 11 & 10 \\
\hline $\mathrm{t} 2.11$ & & $7^{\circ} \mathrm{C} \mathrm{LP}+\mathrm{UVR}$ & Down & 20 & 3 & 19 \\
\hline $\mathrm{t} 2.12$ & & $12{ }^{\circ} \mathrm{C} \mathrm{LP}+\mathrm{UVR}$ & Up & 8 & 1 & 2 \\
\hline $\mathrm{t} 2.13$ & Field & $2{ }^{\circ} \mathrm{C} \mathrm{LP}+\mathrm{UVR}$ & Up & 14 & 3 & 5 \\
\hline $\mathrm{t} 2.14$ & & $2{ }^{\circ} \mathrm{C} \mathrm{LP}+\mathrm{UVR}$ & Down & - & 1 & - \\
\hline $\mathrm{t} 2.15$ & & $7{ }^{\circ} \mathrm{C} \mathrm{LP}+\mathrm{UVR}$ & Up & 9 & 4 & 6 \\
\hline $\mathrm{t} 2.16$ & & $12{ }^{\circ} \mathrm{C} \mathrm{LP}+\mathrm{UVR}$ & Up & 15 & 6 & 4 \\
\hline
\end{tabular}

occurred after the $2{ }^{\circ} \mathrm{C}$ UVR treatment, whereas field grown sporophytes featured highest transcript abundance of this gene under UVR at $12{ }^{\circ} \mathrm{C}$.

Replication factor-a protein (contig20298), replication protein-a 69 kDa DNA-binding subunit (contig07889), and replication protein-a 70 kDa DNA-binding (contig13754) were induced in response to all experimental conditions, the highest transcript abundance was observed in laboratory grown sporophytes after exposure to UVR at $2{ }^{\circ} \mathrm{C}$, field grown sporophytes on the contrary showed highest transcript abundance in response to UVR at $12{ }^{\circ} \mathrm{C}$. Furthermore fold changes of these transcripts were higher in cultivated material exposed to $2^{\circ} \mathrm{C}$ UVR compared to material grown in the field.

3.2.3.3. Vitamin $B_{6}$ metabolism. Two up-regulated transcripts correlated to vitamin $B_{6}$ metabolism were detected, pyridoxal biosynthesis protein pdx2 (contig25393), and pyridoxal 5-phosphate synthase pdxh (contig03286); both were up-regulated in response to all UVR treatments. Transcript abundance at $2{ }^{\circ} \mathrm{C}$ UVR was higher in cultivated material compared to sporophytes obtained from the field, whereas at the $12{ }^{\circ} \mathrm{C}$ UVR treatment induction was stronger in field grown sporophytes than in cultivated sporophytes.

3.2.3.4. ROS scavenging enzymes. Five genes encoding for antioxidative enzymes were simultaneously regulated in cultivated as well as field grown sporophytes. Chloroplastic alternative oxidase (contig10729) was induced in response to all treatments with expression changes between 2.2-fold and 4.9-fold, strongest induction occurred in cultivated and field grown sporophytes after exposure to UVR at $2{ }^{\circ} \mathrm{C}$. Furthermore, UVR at $2{ }^{\circ} \mathrm{C}$ and $7{ }^{\circ} \mathrm{C}$ caused stronger induction of antioxidative enzymes in cultivated material compared to the field grown material, under UVR at $12{ }^{\circ} \mathrm{C}$ sporophytes obtained from the field featured stronger up-regulation. Enhanced transcript abundance of dehydroascorbate reductase (contig06154) was observed in cultivated sporophytes after

Table 3

Enriched metabolic KEGG pathways among the significantly up- and down-regulated genes in different stress conditions identified by KOBAS analysis with a hypergeometric test (FDR corrected $\mathrm{p}<0.01$ )

\begin{tabular}{|c|c|c|c|c|}
\hline Origin & Treatment & Regulation & KEGG pathway & KO ID \\
\hline \multirow[t]{2}{*}{ Culture } & $\mathrm{LP}+\mathrm{UVR} 2{ }^{\circ} \mathrm{C}$ & Up & $\mathrm{ABC}$ transporters & ko02010 \\
\hline & & & Glutathione metabolism & ko00480 \\
\hline \multirow[t]{4}{*}{ Culture } & $\mathrm{LP}+\mathrm{UVR} 2{ }^{\circ} \mathrm{C}$ & Down & Galactose metabolism & ko00052 \\
\hline & & & $\begin{array}{l}\text { Pentose phosphate } \\
\text { pathway }\end{array}$ & ko00030 \\
\hline & & & Glycolysis/gluconeogenesis & ko00010 \\
\hline & & & $\begin{array}{l}\text { Alanine, aspartate and } \\
\text { glutamate metabolism }\end{array}$ & ko00250 \\
\hline Field & $\mathrm{LP}+\mathrm{UVR} 2{ }^{\circ} \mathrm{C} / 7^{\circ} \mathrm{C}$ & Up & Carotenoid biosynthesis & ko00906 \\
\hline
\end{tabular}

exposure to UVR at $2^{\circ} \mathrm{C}$ and $7{ }^{\circ} \mathrm{C}$, and in field grown material in response 412 to UVR at $2^{\circ} \mathrm{C}$ and $12{ }^{\circ} \mathrm{C}$.

Algae from both origins featured induction of L-ascorbate peroxidase 414 (contig00051) after the $2{ }^{\circ} \mathrm{C} / 7^{\circ} \mathrm{C}$ UVR treatment. Additionally we de- 415 tected enhanced transcript abundance of thioredoxin reductase after 416 all treatments except in cultivated sporophytes of the UVR at $12{ }^{\circ} \mathrm{C}$ con- 417 dition, with stronger up-regulation after the $2{ }^{\circ} \mathrm{C} / 7^{\circ} \mathrm{C}$ UVR treatment 418 occurring in cultivated material than in field grown material.

\section{Discussion}

\subsection{Photophysiological responses}

Exposure to UVR in all experiments caused significant decreases in 422 photosynthetic efficiency. Interactive effects of UVR and temperature, 423 with the highest degree of photo inhibition occurring in sporophytes 424 of both origins after UVR exposure at $2{ }^{\circ} \mathrm{C}$ were observed. For no treat- 425 ment a significant difference between field and laboratory grown mate- 426 rial, respectively, could be detected. Thus at the level of $\mathrm{Fv} / \mathrm{Fm} 427$ laboratory sporophytes could not be distinguished from field grown 428 sporophytes and the different pre-incubations of both sporophyte 429 types do not show with this type of measurement. Our results of strong 430 photoinhibition under UVR at low temperatures are consistent with 431 previous studies on the interaction of UVR and temperature in 432 macroalgae. For example sporophytes of the kelp species Alaria 433 esculenta featured higher maximum quantum yield of PS II under simi- 434 lar UV-B radiation conditions at $13^{\circ} \mathrm{C}$ and $17^{\circ} \mathrm{C}$ compared to $4{ }^{\circ} \mathrm{C}$ and 435 $9{ }^{\circ} \mathrm{C}$ (Fredersdorf et al., 2009). Sagert and Schubert (2000) investigated 436 acclimation to light intensity of field and laboratory grown Palmaria 437 palmata (Rhodophyta) and observed no differences in light saturation 438 points $\left(E_{k}\right)$ of photosynthesis. Studies on maximum quantum yield 439 and maximum electron transport rates under UVR stress in A. esculenta 440 from field and culture revealed that the course of acclimation to UVR is 441 similar in plants from field and culture (Bischof et al., 1999). It appears 442 that maximum quantum yield and maximum electron transport rates 443 alone are not sufficient as parameters to distinguish macroalgal labora- 444 tory strains from field grown material.

\subsection{General transcriptomic response}

446

Whereas no differences were obvious at the level of Fv/Fm between 447 laboratory and field grown material we observed large differences in 448 the overall number of regulated genes. From the number of reacting 449 genes (Fig. 2) it seems as if field material needs to activate significantly 450 only half the number of genes to acclimate. We also observed strong in- 451 teractive effects of temperature and UVR on gene expression in cultivat- 452 ed sporophytes, at $12^{\circ} \mathrm{C}$ the number of regulated genes was only half 453 the number of the $2{ }^{\circ} \mathrm{C}$ and $7{ }^{\circ} \mathrm{C}$ treatment.

The higher number of regulated genes, enriched GO terms, and over- 455 represented KEGG metabolic pathways found in cultivated material 456 subjected to UVR indicates that cultivated sporophytes must make 457 stronger efforts of acclimating to UVR than field grown sporophytes. 458 Field plants were taken directly after the ice break-up, and we expected 459 them therefore to be sensitive towards UVR. However we found that 460 field grown sporophytes, based on gene and GO numbers, are less sen- 461 sitive to UVR@@@ than cultivated sporophytes. One reason for this 462 might be the possible different age of the thalli. We knew the age of lab- 463 oratory sporophytes at 5-7 cm length (ca. 8 weeks) but we can only es- 464 timate the age of equally long field grown sporophytes, which could 465 have been 4-5 months old, sporophytes obtained from the field were 466 thicker, more stable, and appeared darker. Studies on S. latissima re- 467 vealed differences in UVR sensitivity with respect to the age of the thalli, 468 which is partly due to age-dependent morpho-functional features 469 (Bischof et al., 2002b; Dring et al., 1996). For plants it was shown that 470 exposure to a single stress agent can lead to increased resistance to sub- 471 sequent unfavorable impacts (Alexieva et al., 2003). This might be also 472 
Table 4

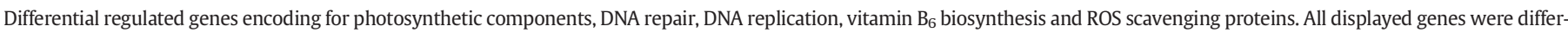
entially expressed with FDR corrected $\mathrm{p}<0.01$ and were considered to be significant differently expressed with a fold change $>2$ (numbers in bold).

\begin{tabular}{|c|c|c|c|c|c|c|c|}
\hline \multirow[t]{3}{*}{ Contig name } & \multirow[t]{3}{*}{ Putative gene product } & \multicolumn{6}{|l|}{ Fold change } \\
\hline & & \multicolumn{3}{|l|}{ Culture } & \multicolumn{3}{|l|}{ Field } \\
\hline & & $2{ }^{\circ} \mathrm{C} \mathrm{LP}+\mathrm{UVR}$ & $7^{\circ} \mathrm{C} \mathrm{LP}+\mathrm{UVR}$ & $12^{\circ} \mathrm{C} \mathrm{LP}+\mathrm{UVR}$ & $2{ }^{\circ} \mathrm{C} \mathrm{LP}+\mathrm{UVR}$ & $7{ }^{\circ} \mathrm{C} \mathrm{LP}+\mathrm{UVR}$ & $12^{\circ} \mathrm{C} \mathrm{LP}+\mathrm{UVR}$ \\
\hline \multicolumn{8}{|c|}{ Photosynthetic components } \\
\hline Contig02465 & Cytochrome b6 complex & 2.5 & 2.2 & 2.4 & 2.5 & 2.4 & 3.2 \\
\hline Contig13579 & Fucoxanthin-chlorophyll a-c binding protein & 19.7 & 20.5 & 1.2 & 253.9 & 8.7 & 7.5 \\
\hline Contig24218 & Light harvesting complex protein & -3.2 & -4.8 & -1.1 & -3.2 & -1.2 & -1.6 \\
\hline Contig08085 & Light-harvesting complex I $21 \mathrm{kDa}$ & -3.2 & -4.9 & -1.1 & -7.0 & -1.4 & -2.0 \\
\hline Contig03513 & Photosystem I reaction center subunit II & 1.3 & 2.4 & 1.9 & 2.9 & 2.3 & 2.2 \\
\hline Contig02889 & Photosystem II biogenesis protein psp29 & 3.6 & 2.5 & 1.7 & 5.1 & 3.5 & 2.4 \\
\hline Contig03429 & Photosystem II D2 protein & 2.3 & 2.5 & 2.4 & 2.9 & 2.1 & 3.3 \\
\hline Contig14092 & Photosystem II protein & 1.7 & 2.8 & 1.8 & 3.0 & 1.6 & 1.6 \\
\hline Contig02680 & Photosystem II stability assembly factor hcf136 & 2.0 & 3.5 & 2.1 & 2.8 & 1.8 & 2.3 \\
\hline \multicolumn{8}{|l|}{ DNA repair } \\
\hline Contig21643 & Deoxyribodipyrimidine photolyase family & 3.4 & 3.1 & 1.1 & 3.5 & 2.0 & 2.2 \\
\hline Contig04132 & DNA repair protein uvh3 & 4.2 & 3.5 & 2.6 & 2.8 & 1.8 & 4.7 \\
\hline Contig07877 & Rad51 DNA recombination repair protein & 4.4 & 4.9 & 1.8 & 4.5 & 3.1 & 3.1 \\
\hline Contig20298 & Replication factor-a protein & 3.7 & 3.0 & 2.9 & 3.2 & 4.1 & 4.6 \\
\hline Contig07889 & Replication protein-a 69 kDa DNA-binding subunit & 3.1 & 3.1 & 2.6 & 2.6 & 2.8 & 3.3 \\
\hline Contig13754 & Replication protein-a 70 kDa DNA-binding & 3.1 & 2.9 & 3.0 & 2.8 & 3.4 & 3.4 \\
\hline Contig06170 & X-ray repair cross-complementing protein 6 & 2.4 & 2.2 & 1.7 & 3.5 & 4.6 & 3.6 \\
\hline \multicolumn{8}{|c|}{ Vitamin $B_{6}$ biosynthesis } \\
\hline Contig25393 & Pyridoxal biosynthesis protein pdx2 & 4.6 & 3.1 & 2.1 & 3.2 & 4.3 & 2.7 \\
\hline Contig03286 & Pyridoxal 5-phosphate synthase pdxh & 4.5 & 5.6 & 2.2 & 4.0 & 2.5 & 2.7 \\
\hline \multicolumn{8}{|c|}{ ROS scavengers } \\
\hline Contig10729 & Alternative oxidase chloroplastic & 4.9 & 4.6 & 2.2 & 3.9 & 2.7 & 2.4 \\
\hline Contig06154 & Dehydroascorbate reductase & 3.8 & 5.1 & 1.9 & 4.1 & 1.7 & 2.3 \\
\hline Contig00051 & L-Ascorbate peroxidase & 3.6 & 5.0 & 1.6 & 7.4 & 3.4 & 1.9 \\
\hline Contig08467 & Thioredoxin reductase & 8.9 & 9.5 & 1.6 & 7.9 & 6.2 & 4.7 \\
\hline Contig27363 & Thioredoxin-like protein & 3.6 & 2.6 & -2.4 & 7.4 & 1.1 & 1.3 \\
\hline
\end{tabular}

the case for field grown sporophytes of S. latissima, as exposure to cold temperatures might have led to an increased resistance to UV-B radiation. It is also possible that field grown sporophytes, exposed to natural rhythms (such as day length) and depending on them, was "expecting" and pre-adapting to increased UVR along with the increased light intensity of thinning ice before break-up.

\subsection{Specific transcriptional responses}

Similarities of transcriptomic response to UVR in cultivated and field grown Saccharina include enhanced regulation of photosynthetic components and DNA repair. Several studies on UVR stress in macroalgae demonstrated that UVR influences photosynthesis negatively and causes DNA damage (Karsten et al., 2011). Our transcriptomic data support these findings, indicating that photosynthesis and DNA are main targets of UVR in macroalgae.

Even though the origin of the sporophytes did not significantly influence the maximum quantum yield of photosystem (PS) II, it led to differences in the overall number of regulated genes coding for photosynthetic components, with a larger number of reacting genes in cultured sporophytes. Furthermore different expression fold changes of genes simultaneously regulated in cultivated and field grown material were observed. Transcripts encoding for light harvesting complex proteins show diverse regulation patterns in response to UVR, light harvesting complex protein and light-harvesting complex I $21 \mathrm{kDa}$ showed stronger repression in sporophytes from culture while fucoxanthinchlorophyll a-c binding protein was stronger induced in field grown sporophytes. The latter transcript was strongly up-regulated in response to the UVR treatments in both field and culture material. It was recently shown in diatoms that some members of the LHCX subfamilies of LHC genes are induced under light stress, here the authors suggested that this induction is part of a photo-protective response (Bailleul et al.,
2010; Zhu and Green, 2010). The observed up-regulation of the 503 fucoxanthin-chlorophyll a-c binding protein to UVR stress in 504 S. latissima indicates a role in photo-protection. It appears that the in- 505 duction of LHCs is a component of the short term and long-term accli- 506 mation of photosynthesis to both, high PAR and UVR, in S. latissima 507 (Heinrich et al., 2012b, 2015). 4 genes associated with photosystem II 508 and one gene correlated to photosystem I were detected. Photosystem 509 I reaction centre subunit II was induced in all field grown sporophyte 510 experiments, but only after one treatment in cultivated material, indi- 511 cating a higher protein turnover rate of PS I reaction centre under UVR 512 in field grown sporophytes compared to cultivated sporophytes. Tran- 513 scripts associated to photosystem II, e.g. photosystem II D2 protein, 514 were up-regulated in response to most of the UVR treatments, usually 515 with higher induction in field grown material. The higher number of 516 regulated transcripts as well as higher number of treatments featuring 517 regulation of these genes indicates that photosystem II is more sensitive 518 to UVR than photosystem I. This agrees with former studies, which 519 demonstrated that PS II is more prone to harmful effects of UVR than 520 PS I (Franklin et al., 2003; Vass et al., 2005). Moreover it was shown in 521 several studies on macroalgae that UVR leads to degradation of several 522 photosynthetic components, and recovery mechanisms include degra- 523 dation and biosynthesis of damaged photosynthetic reaction centre 524 proteins (Bischof et al., 2006; Franklin et al., 2003). For cyanobacteria 525 it was demonstrated that repair of UVR damaged PS II reaction centre 526 by increasing the transcript pool (Campbell et al., 1998; Huang et al., 527 2002). We therefore suggest that the induction of transcripts encoding 528 for PS I, and PS II might be reflecting enhanced repair rates of photosyn- 529 thetic proteins due to an increased turnover rate under UVR stress. The 530 observed differences in gene expression of photosynthetic components 531 under UVR in cultivated and field grown sporophytes of S. latissima 532 might be, despite of the similar size of the thalli, caused by differences 533 in age-dependent morpho-functional features of field grown and 534 
cultivated sporophytes. This finding is consistent with a previous study, where it was shown that the acclimation to high irradiance increases with age of sporophytes in S. latissima (Hanelt et al., 1997).

UVR exposure caused in all treatments induction of transcripts correlated to DNA repair. Transcripts correlated to replication factor protein-a, e.g. replication protein-a $70 \mathrm{kDa}$ DNA-binding, were induced after all UVR treatments, with highest transcript abundance in cultivated sporophytes after exposure to UVR at $2{ }^{\circ} \mathrm{C}$, in field grown sporophytes after UVR at $12{ }^{\circ} \mathrm{C}$. Replication protein-a binds to singlestranded DNA, which is involved in DNA replication, DNA-repair and recombination (Wold, 1997). It is essential for nucleotide excision repair, where it interacts with DNA repair enzymes at sites of DNA damage, and repair of double-strand breaks by homologous recombination (Buschta-Hedayat et al., 1999; Stauffer and Chazin, 2004). Studies on Oryza sativa and Arabidopsis thaliana revealed different types of replication protein-a $70 \mathrm{kDa}$, and transcripts encoding for these proteins showed induction in response to high levels of UVR, and are therefore suggested to be required for repair of UVR-damaged DNA (Ishibashi et al., 2001, 2005). Four genes encoding for DNA repair enzymes were discovered, three of them showed enhanced transcript abundance after all UVR treatments except in cultivated sporophytes after the UVR $12{ }^{\circ} \mathrm{C}$ condition. Induction profiles of these transcripts were dependent not only on temperature and origin, but also on interaction of these two factors. A deoxyribodipyrimidine photolyase family protein showed highest induction in both origins after the $2{ }^{\circ} \mathrm{C}$ UVR treatment, $\mathrm{X}$-ray repair cross-complementing protein 6 showed generally higher fold changes in field grown sporophytes than in cultivated sporophytes, whereas DNA repair protein uvh3 featured highest transcript abundance in cultivated material after the $2{ }^{\circ} \mathrm{C}$ UVR treatment, in field grown material after the $12{ }^{\circ} \mathrm{C}$ UVR condition. These results indicate that the experimental UVR radiation led to severe DNA damage. UVR induces oxidative damage to DNA; double-strand breaks of DNA crosslinks between DNA-protein and DNA-DNA and enhanced formation of cyclobutane-pyrimidine dimers (CPDs) (Britt, 1999; Hall et al., 1992). CPDs inhibit genome replication and gene expression as a consequence disruption in cell metabolism and division occurs (Buma et al., 1995; van De Poll et al., 2001). In plants CPDs are predominantly repaired by photoreactivation, a light dependent process during which photolyases bind specifically to CPDs and directly reverse the damage (Britt, 1996). A study on interactive effects of UVR and temperature on photoreactivation in P. palmata demonstrated that light dependent removal of CPDs increases with rising temperatures (Pakker et al., 2000b). We suggest the similar case for S. latissima, as the highest induction of deoxyribodipyrimidine photolyase family protein occurred under UVR at $2{ }^{\circ} \mathrm{C}$, indicating that light dependent photoreactivation has lower kinetic rates at $2{ }^{\circ} \mathrm{C}$ than at $12{ }^{\circ} \mathrm{C}$. We observed upregulation of rad51 DNA recombination repair protein, which is involved in homologous recombination, a mechanism for repairing double-strand breaks and single strand gaps in damaged DNA (Markmann-Mulisch et al., 2007; Sinha and Häder, 2002). Furthermore induction of DNA repair protein uvh3 was detected, a putative singlestranded DNA endonuclease involved in nucleotide excision repair of UVR- and oxidative damaged DNA (Liu et al., 2001). Our data indicate that acclimation to UVR in S. latissima includes sophisticated regulation of three different DNA repair processes, namely photoreactivation, homologous recombination and nucleotide excision repair.

Sporophytes of both origins responded to UVR stress with an induction of the vitamin $B_{6}$ metabolism with a stronger induction of the vitamin $B_{6}$ metabolism in cultivated sporophytes compared to field grown sporophytes. Both relevant transcripts, pyridoxal 5-phosphate synthase pdxh and pyridoxal biosynthesis proteins pdx 1 , were most strongly induced in response to UVR at low temperatures. Vitamin $B_{6}$ acts as an important cofactor for a large number of essential enzymes, and exhibits an antioxidant activity comparable to that of vitamins $\mathrm{C}$ and $\mathrm{E}$ (Ehrenshaft et al., 1999; González et al., 2007; Leuendorf et al., 2010). Studies in Arabidopsis showed that vitamin $\mathrm{B}_{6}$ is linked to stress responses, and is crucial for acclimation to oxidative, osmotic, high 601 light and UVR stress (Chen and Xiong, 2005; González et al., 2007; 602 Ristilä et al., 2011; Titiz et al., 2006). Vitamin $\mathrm{B}_{6}$ deficient Arabidopsis 603 plants exhibit increased sensitivity to photo-oxidative stress and the au- 604 thors proposed that vitamin B6 functions in photo-protection limiting 605 oxidative damage (Havaux et al., 2009). Our studies indicate that the 606 regulation of the vitamin $\mathrm{B}_{6}$ biosynthesis is a crucial part of the acclima- 607 tion mechanism against abiotic stress in S. latissima (Heinrich et al., 608 2012b, 2015).

We identified several regulated genes encoding for reactive oxygen 610 species (ROS) scavenging enzymes. UVR, and other physiological stress 611 conditions, triggers the synthesis of ROS (Contreras et al., 2009; Kumar 612 et al., 2010). ROS are highly toxic, cause cellular damage and need to be 613 rapidly detoxified by cellular scavenging mechanisms (Apel and Hirt, 614 2004; Asada, 1997; Foyer and Noctor, 2005). Several studies demon- 615 strated the involvement of ROS species in response to biotic and abiotic 616 stresses in macroalgae; increased activity of ROS scavenging enzymes 617 has been shown after exposure to UVR stress, low temperature and des- 618 iccation (Aguilera et al., 2002; Bischof et al., 2003; Burritt et al., 2002; 619 Collén and Davison, 2001; Contreras et al., 2009). Stronger induction 620 of transcripts associated with ROS scavenging enzymes at $2{ }^{\circ} \mathrm{C}$ than at 621 $12{ }^{\circ} \mathrm{C}$ was observed, indicating a higher oxidative stress level at low 622 temperatures. This might be either due to enhanced generation of ROS 623 at low temperatures, or to decreasing kinetic rates of ROS scavenging 624 with declining temperatures. Interestingly most ROS scavenging en- 625 zymes were induced in field grown sporophytes of S. latissima subjected 626 to UVR at $12^{\circ} \mathrm{C}$, whereas only one up-regulated transcript was detected 627 after this treatment in cultivated material. This might reflect lower oxi- 628 dative stress levels in cultivated material at $12{ }^{\circ} \mathrm{C}$. The low growth tem- 629 perature of field grown sporophytes of S. latissima in Spitsbergen might 630 have led to metabolic alterations, which allow for a better performance 631 of stress response at lower temperatures, but at the same time for a 632 higher sensitivity towards increasing temperatures.

\section{Summary and conclusions}

Our results indicate that cultivated sporophytes undergo a larger 635 scale transcriptomic reorganization for acclimating to UVR and changes 636 in temperature than field grown sporophytes. Interestingly a differenti- 637 ation in terms of molecular processes was not observed here. Origin of 638 the sporophytes had no influence on maximum quantum yield of pho- 639 tosystem II, observed differences in gene expression of photosynthetic 640 components under UVR of S. latissima might be caused by differences 641 in age-dependent morpho-functional features. Main effects of UVR, 642 targeting mostly photosynthesis and DNA, were similar in cultivated 643 and field grown sporophytes, which show that laboratory experiments 644 are well suited to investigate basic molecular mechanisms of acclima- 645 tion to abiotic stresses. The higher induction rates of transcripts associ- 646 ated with ROS scavenging indicate a higher sensitivity to UVR and a 647 higher oxidative stress level at $12{ }^{\circ} \mathrm{C}$ in field compared to cultivated spo- 648 rophytes. At the same time cultivated sporophytes grown at $10^{\circ} \mathrm{C}$ must 649 make stronger efforts of acclimating to UVR at $2{ }^{\circ} \mathrm{C}$ than field grown 650 sporophytes, which were exposed to low temperatures for about 651 4-5 months. This is reflected by the finding that at $12{ }^{\circ} \mathrm{C}$ the num- 652 ber of regulated genes was only half compared to the $2{ }^{\circ} \mathrm{C}$ and $7{ }^{\circ} \mathrm{C} 653$ treatment in cultivated sporophytes. These results demonstrate the in- 654 fluence of growth conditions on the acclimation to stress on the tran- 655 scriptional level. We suggest that acclimation of S. latissima from the 656 field to low temperatures caused metabolic alterations to increase stress 657 performance at low temperatures, and concurrently led to higher sus- 658 ceptibility at $12{ }^{\circ} \mathrm{C}$. Our results furthermore underscore the importance 659 of conducting experiments with field grown material for the prediction 660 of biological and environmental effects of changing abiotic factors in the 661 ecosystem.

Supplementary data to this article can be found online at http://dx. 663 doi.org/10.1016/j.jembe.2015.12.006. 


\section{Acknowledgments}

This research was funded by the Alfred Wegener Institute Helmholtz Centre for Polar and Marine Research. We would like to thank the diving group of the Alfred Wegener Institute headed by Max Schwanitz for collection of algal material. This study was performed at the Ny-Ålesund International Research and Monitoring Facility in Svalbard. [SW]

\section{References}

Aguilera, J., Dummermuth, A., Karsten, U., Schriek, R.,Wiencke, C., 2002. Enzymatic defences against photooxidative stress induced by ultraviolet radiation in Arctic marine macroalgae. Polar Biol. 25 (6), 432-441.

Alexieva, V., Ivanov, S., Sergiev, I., Karanov, E., 2003. Interaction between stresses. Bulg. J. Plant Physiol. 1-17 (special issue).

Apel, K., Hirt, H., 2004. Reactive oxygen species: metabolism, oxidative stress, and signal transduction. Annu. Rev. Plant Biol. 55, 373-399.

Asada, K., 1997. The role of ascorbate peroxidase and monodehydroascorbate reductase in $\mathrm{H}_{2} \mathrm{O}_{2}$ scavenging in plants. In: JG, S. (Ed.), Oxidative Stress and the Molecular Biology of Antioxidant Defenses. Cold Spring Harbor Laboratory Press, New York.

Bailleul, B., Rogato, A., de Martino, A., Coesel, S., Cardol, P., Bowler, C., Falciatore, A., Finazzi, G., 2010. An atypical member of the light-harvesting complex stress-related protein family modulates diatom responses to light. Proc. Natl. Acad. Sci. U. S. A. 107 (42), 18214-18219.

Bartsch, I., Wiencke, C., Bischof, K., Buchholz, C., Buck, B., Eggert, A., Feuerpfeil, P., Hanelt D., Jacobsen, S., Karez, R., Karsten, U., Molis, M., Roleda, M., Schubert, H., Schumann, R, Valentin, K., Weinberger, F., Wiese, J., 2008. The genus Laminaria sensu lato: recent insights and developments. Eur. J. Phycol. 43 (1), 1-86.

Bartsch, I., Wiencke, C., Laepple, C., 2012. Global seaweed biogeography under a changing climate: the prospected effects of temperature. In: Wiencke, C., Bischof, K. (Eds.), Seaweed Biology: Novel Insights into Ecophysiology, Ecology and Utilization. Springer Verlag, Heidelberg.

Benjamini, Y., Hochberg, Y., 1995. Controlling the false discovery rate - a practical and powerful approach to multiple testing. J. R. Stat. Soc. Ser. B Methodol. 57 (1), 289-300.

Bischof, K., Gómez, I., Molis, M., Hanelt, D., Karsten, U., Lüder, U., Roleda, M., Zacher, K. Wiencke, C., 2006. Ultraviolet radiation shapes seaweed communities. Rev. Environ. Sci. Biotechnol. 5 (2-3), 141-166.

Bischof, K., Hanelt, D., Tüg, H., Karsten, U., Brouwer, P., Wiencke, C., 1998. Acclimation of brown algal photosynthesis to ultraviolet radiation in Arctic coastal waters (Spitsbergen, Norway). Polar Biol. 20 (6), 388-395.

Bischof, K., Hanelt, D., Wiencke, C., 1999. Acclimation of maximal quantum yield of photosynthesis in the brown alga Alaria esculenta under high light and UV radiation. Plant Biol. 1, 435-444.

Bischof, K., Hanelt, D., Wiencke, C., 2000. Effects of ultraviolet radiation on photosynthesis and related enzyme reactions of marine macroalgae. Planta 211, 555-562.

Bischof, K., Janknegt, P., Buma, A., Rijstenbil, J., Peralta, G., Breeman, A., 2003. Oxidative stress and enzymatic scavenging of superoxide radicals induced by solar UV-B radiation in Ulva canopies from southern Spain. Sci. Mar. 67 (3), 353-359.

Bischof, K, Kräbs, G, Wiencke, C. Hanelt, D, 2002a. Solar ultraviolet radiation affects the activity of ribulose-1,5-bisphosphate carboxylase-oxygenase and the composition of photosynthetic and xanthophyll cycle pigments in the intertidal green alga Ulva lactuca L. Planta 215 (3), 502-509.

Bischof, K.B., Hanelt, D.H., Aguilera, J.A., Karsten, U.K., Vögele, B.V., Sawall, T.S., Wiencke, C.W., 2002b. Seasonal variation in ecophysiological patterns in macroalgae from an Arctic fjord. I. Sensitivity of photosynthesis to ultraviolet radiation. Mar. Biol. 140 (6), 1097-1106

Bolton, J.J., Germann, I., Lüning, K., 1983. Hybridization between Atlantic and Pacific representatives of the simplices section of Laminaria (Phaeophyta). Phycologia 22 (2), $133-140$.

Borum, J., Pedersen, M., Krause Jensen, D., Christensen, P., Nielsen, K., 2002. Biomass, photosynthesis and growth of Laminaria saccharina in a high-Arctic fjord, NE Greenland. Mar. Biol. 141 (1), 11-19.

Britt, A.B., 1996. DNA damage and repair in plants. Annu. Rev. Plant Physiol. Plant Mol. Biol. 47, 75-100

Britt, A.B., 1999. Molecular genetics of DNA repair in higher plants. Trends Plant Sci. 4 (1), $20-25$.

Buma, A.G.J., van Hannen, E.J., Roza, L., Veldhuis, M.J.W., Gieskes, W.W.C., 1995. Monitoring ultraviolet-B-induced DNA damage in individual diatom cells by immunofluorescent thymine dimer detection. J. Phycol. 31 (2), 314-321.

Burritt, D. Larkindale, J.. Hurd, C. 2002. Antioxidant metabolism in the intertidal red seaweed Stictosiphonia arbuscula following desiccation. Planta 215 (5), 829-838.

Buschta-Hedayat, N., Buterin, T., Hess, M.T., Missura, M., Naegeli, H., 1999. Recognition of nonhybridizing base pairs during nucleotide excision repair of DNA. Proc. Natl. Acad. Sci. 96 (11), 6090-6095.

Campbell, D., Eriksson, M.J., Oquist, G., Gustafsson, P., Clarke, A.K., 1998. The cyanobacterium Synechococcus resists UV-B by exchanging photosystem II reaction-center D1 proteins. Proc. Natl. Acad. Sci. U. S. A. 95 (1), 364-369.

Carlsen, B., Johnsen, G., Berge, J., Kuklinski, P., 2007. Biodiversity patterns of macroepifauna on different lamina parts of Laminaria digitata and Saccharina latissima collected during spring and summer 2004 in Kongsfjorden, Svalbard. Polar Biol. 30 (7) 939-943.
Charpy-Roubaud, C., Sournia, A., 1990. The comparative estimation of phytoplanktonic, 744 microphytobenthic and macrophytobenthic primary productions in the oceans. 745 Mar. Microb. Food Webs 4 (1), 31-57.

Chen, H., Xiong, L., 2005. Pyridoxine is required for post-embryonic root development and 747 tolerance to osmotic and oxidative stresses. Plant J. 44 (3), 396-408. 748

Collén, J., Davison, I.R., 2001. Seasonality and thermal acclimation of reactive oxygen me- 749 tabolism in Fucus vesiculosus (Phaeophyceae). J. Phycol. 37 (4), 474-481.

Conesa, A., Gotz, S., Garcia-Gomez, J., Terol, J., Talon, M., Robles, M., 2005. Blast2GO: a uni- 751 versal tool for annotation, visualization and analysis in functional genomics research. 752 Bioinformatics 21, 3674-3676.

Contreras, L., Mella, D., Moenne, A., Correa, J.A., 2009. Differential responses to copper- 754 induced oxidative stress in the marine macroalgae Lessonia nigrescens and 755 Scytosiphon lomentaria (Phaeophyceae). Aquat. Toxicol. 94 (2), 94-102. 756

Davison, I., Jordan, T., Fegley, J., Grobe, C., 2007. Response of Laminaria saccharina 757 (Phaeophyta) growth and photosynthesis to simultaneous ultraviolet radiation and 758 nitrogen limitation. J. Phycol. 43 (4), 636-646.

Dring, M.J., Makarov, V., Schoschina, E., Lorenz, M., Lüning, K., 1996. Influence of 760 ultraviolet-radiation on chlorophyll fluorescence and growth in different life- 761 history stages of three species of Laminaria (Phaeophyta). Mar. Biol. 126 (2), 762 183-191.

Ehrenshaft, M., Bilski, P., Li, M.Y., Chignell, C.F., Daub, M.E., 1999. A highly conserved se- 764 quence is a novel gene involved in de novo vitamin $\mathrm{B}_{6}$ biosynthesis. Proc. Natl. 765 Acad. Sci. 96 (16), 9374-9378.

Foyer, C.H., Noctor, G., 2005. Oxidant and antioxidant signalling in plants: a re-evaluation 767 of the concept of oxidative stress in a physiological context. Plant Cell Environ. 28 (8), 768 1056-1071. 769

Franklin, L., Osmond, C., Larkum, A., 2003. Photoinhibition, UV-B and algal photosynthesis. 770 In: Larkum, A.W.D., Douglas, S.E., Raven, J.A. (Eds.), Photosynthesis in Algae. Kluwer 771 Academic Publishers, Dordrecht, pp. 351-384

Fredersdorf, J., Müller, R., Becker, S., Wiencke, C., Bischof, K., 2009. Interactive effects of ra- 773 diation, temperature and salinity on different life history stages of Arctic kelp Alaria 774 esculenta (Phaeophyceae). Oecologia 160, 483-492.

Cerard V. 1988. Ecotypic differentiation in light-related traits of the kelp Laminaria 776 saccharina. Mar. Biol. 97, 25-36.

González, E., Danehower, D., Daub, M.E., 2007. Vitamer levels, stress response, enzyme ac- 778 tivity, and gene regulation of Arabidopsis lines mutant in the pyridoxine/pyridox- 779 amine 5'-phosphate oxidase (PDX3) and the pyridoxal kinase (SOS4) genes 780 involved in the vitamin $B_{6}$ salvage pathway. Plant Physiol. 145 (3), 985-996. 781

Hall, R.D., Rouwendal, G.J.A., Krens, F.A., 1992. Asymmetric somatic cell hybridization in 782 plants. Mol. Gen. Genet. MGG 234 (2), 315-324 783

Hanelt, D., 1998. Capability of dynamic photoinhibition in Arctic macroalgae is related to 784 their depth distribution. Mar. Biol. 131 (2), 361-369.

Hanelt, D., Wiencke, C., Karsten, U., Nultsch, W., 1997. Photoinhibition and recovery after 786 high light stress in different developmental and life-history stages of Laminaria 787 saccharina (Phaeophyta). J. Phycol. 33 (3), 387-395.

Harley, C.D.G., Hughes, A.R., Hultgren, K.M., Miner, B.G., Sorte, C.J.B., Thornber, C.S., 789 Rodriguez, L.F., Tomanek, L., Williams, S.L., 2006. The impacts of climate change in 790 coastal marine systems. Ecol. Lett. 9 (2), 228-241.

Havaux, M., Ksas, B., Szewczyk, A., Rumeau, D., Franck, F., Caffarri, S., Triantaphylidès, C., 792 2009. Vitamin $B_{6}$ deficient plants display increased sensitivity to high light and 793 photo-oxidative stress. BMC Plant Biol. 9 (1), 1-22.

Hawkins, S.J., Sugden, H.E., Mieszkowska, N., Moore, P.J., Poloczanska, E., Leaper, R., 795 Herbert, R.J.H., Genner, M.J., Moschella, P.S., Thompson, R.C., Jenkins, S.R., 796 Southward, A.J., Burrows, M.T., 2009. Consequences of climate-driven biodiversity 797 changes for ecosystem functioning of North European rocky shores. Mar. Ecol. Prog. 798 Ser. 396, 245-259.

Heinrich, S., Frickenhaus, S, Glöckner, G, Valentin, K, 2012a. A comprehensive cDNA li- 800 brary of temperature stressed Saccharina latissima (Phaeophyceae). Eur. J. Phycol. 801 47 (2), 83-94

Heinrich, S., Valentin, K., Frickenhaus, S., John, U., Wiencke, C., 2012b. Transcriptomic 803 analysis of acclimation to temperature and light stress in Saccharina latissima 804 (Phaeophyceae). PLoS One 7 (8).

Heinrich, S., Valentin, K., Frickenhaus, S., Wiencke, C., 2015. Temperature and light inter- 806 actively modulate gene expression in Saccharina latissima (Phaeophyceae). J. Phycol. 807 51, 93-108.

Helmuth, B., Mieszkowska, N., Moore, P., Hawkins, S.J., 2006. Living on the edge of two 809 changing worlds: forecasting the responses of rocky intertidal ecosystems to climate 810 change. Annu. Rev. Ecol. Evol. Syst. 37 (1), 373-404.

Hoffman, J.R., Hansen, L.J., Klinger, T., 2003. Interactions between UV radiation and 812 temperature limit inferences from single-factor experiments. J. Phycol. 39 (2), 813 268-272.

Huang, L., McCluskey, M.P., Ni, H., LaRossa, R.A., 2002. Global gene expression profiles of 815 the cyanobacterium Synechocystis sp. Strain PCC 6803 in response to irradiation 816 with UV-B and white light. J. Bacteriology 184 (24), 6845-6858.

IPCC, 2001. Climate Change 2001, Synthesis Report. A Contribution of Working Croups I, 817 II, and III to the Third Assessment Report of the Intergovernmental Panel on Climate 819 Change.In: Press, C.U. (Ed.), Cambridge, UK.

IPCC, 2007. Intergovernmental Panel on Climate Change. Climate change 2007: The Phys- 821 ical Science Basis. Contribution of Working Group I to the fourth assessment. In: 822 Press, C.U. (Ed.), Cambridge, UK, pp. 996.

Ishibashi, T., Kimura, S., Furukawa, T., Hatanaka, M., Hashimoto, J., Sakaguchi, K., 2001. 824 Two types of replication protein A 70 kDa subunit in rice, Oryza sativa: molecular 825 cloning, characterization, and cellular \& tissue distribution. Gene 272 (1-2), 335-343. 826

Ishibashi, T., Koga, A., Yamamoto, T., Uchiyama, Y., Mori, Y., Hashimoto, J., Kimura, S., 827 Sakaguchi, K., 2005. Two types of replication protein A in seed plants. FEBS J. 272828 (13), 3270-3281. 
Karsten, U., Wulff, A., Roleda, M., Müller, R., Steinhoff, F., Fredersdorf, J., Wiencke, C., 2011. Physiological responses of polar benthic algae to ultraviolet radiation. In: Wiencke, C. (Ed.), Biology of Polar Benthic Algae. de Gruyter, Berlin.

Kerr, J.B., McElroy, C.T., 1993. Evidence for large upward trends of ultraviolet-B radiation linked to ozone depletion. Science 262 (5136), 1032-1034

Kumar, M., Kumari, P., Gupta, V., Anisha, P., Reddy, C., Jha, B., 2010. Differential responses to cadmium induced oxidative stress in marine macroalga Ulva lactuca (Ulvales, Chlorophyta). Biometals 23 (2), 315-325.

Leuendorf, J.E., Osorio, S., Szewczyk, A., Fernie, A.R., Hellmann, H., 2010. Complex assembly and metabolic profiling of Arabidopsis thaliana plants overexpressing vitamin $\mathrm{B}_{6}$ biosynthesis proteins. Mol. Plant 3 (5), 890-903.

Lima, F.P., Ribeiro, P.A., Queiroz, N., Hawkins, S.J., Santos, A.M., 2007. Do distributional shifts of northern and southern species of algae match the warming pattern? Glob. Chang. Biol. 13 (12), 2592-2604.

Lippert, H., Iken, K., Rachor, E., Wiencke, C., 2001. Macrofauna associated with macroalgae in the Kongsfjord (Spitsbergen). Polar Biol. 24, 512-522.

Liu, Z., Hall, J.D., Mount, D.W., 2001. Arabidopsis UVH3 gene is a homolog of the Saccharomyces cerevisiae RAD2 and human XPG DNA repair genes. Plant J. 26 (3), 329-338.

Lüning, K., 1990. Seaweeds. Their Environment, Biogeography and Ecophysiology. Wiley \& Sons Inc., New York.

Madronich, S., McKenzie, R.L., Björn, L.O., Caldwell, M.M., 1998. Changes in biologically active ultraviolet radiation reaching the Earth's surface. J. Photochem. Photobiol. B Biol. 46 (1-3), 5-19.

Manney, G.L., Santee, M.L., Rex, M., Livesey, N.J., Pitts, M.C., Veefkind, P., Nash, E.R. Wohltmann, I., Lehmann, R., Froidevaux, L., Poole, L.R., Schoeberl, M.R., Haffner, D.P., Davies, J., Dorokhov, V., Gernandt, H., Johnson, B., Kivi, R., Kyro, E., Larsen, N., Levelt, P.F., Makshtas, A., McElroy, C.T., Nakajima, H., Parrondo, M.C., Tarasick, D.W., von der Gathen, P., Walker, K.A., Zinoviev, N.S., 2011. Unprecedented Arctic ozone loss in 2011. Nature 478 (7370), 469-475.

Markmann-Mulisch, U., Wendeler, E., Zobell, O., Schween, G., Steinbiss, H.-H., Reiss, B. 2007. Differential requirements for RAD51 in Physcomitrella patens and Arabidopsis thaliana development and DNA damage repair. Plant Cell 19 (10), 3080-3089 (Online).

Merzouk, A., Johnson, L.E., 2011. Kelp distribution in the northwest Atlantic Ocean under a changing climate. J. Exp. Mar. Biol. Ecol. 400 (1-2), 90-98.

Müller, R., Wiencke, C., Bischof, K., 2008. Interactive effects of UV radiation and temperature on microstages of Laminariales (Phaeophyceae) from the Arctic and North Sea. Clim. Res. 37 (2-3), 203-213.

Pakker, H., Beekman, C., Breeman, A., 2000a. Efficient photoreactivation of UVBR-induced DNA damage in the sublittoral macroalga Rhodymenia pseudopalmata (Rhodophyta). Eur. J. Phycol. 35 (2), 109-114.

Pakker, H., Martins, R.S.T., Boelen, P., Buma, A.G.J., Nikaido, O., Breeman, A.M., 2000b. Effects of temperature on the photoreactivation of ultraviolet-B-induced DNA damage in Palmaria palmata (Rhodophyta). J. Phycol. 36 (2), 334-341.

Rautenberger, R., Bischof, K., 2006. Impact of temperature on UV-susceptibility of two Ulva (Chlorophyta) species from Antarctic and Subantarctic regions. Polar Biol. 29 (11), 988-996.

Ristilä, M., Strid, H., Eriksson, L.A., Strid, Å., Sävenstrand, H., 2011. The role of the pyridoxine (vitamin $\mathrm{B}_{6}$ ) biosynthesis enzyme PDX1 in ultraviolet-B radiation responses in plants. Plant Physiol. Biochem. 49 (3), 284-292.

Roleda, M., Hanelt, D., Wiencke, C., 2006. Growth and DNA damage in young Laminaria sporophytes exposed to ultraviolet radiation: implication for depth zonation of kelps on Helgoland (North Sea). Mar. Biol. 148 (6), 1201-1211.
Roleda, M. Wiencke, C , Hanelt, D., Bischof, K, 2007. Sensitivity of the early life stages of 883 macroalgae from the northern hemisphere to ultraviolet radiation. Photochem. 884 photobiol. 83 (4), 851-862.

Sagert, S., Schubert H. 2000. Acclimation of Palmaria palmata (Rhodophyta) to light in- 886 tensity: comparison between artificial and natural light fields. J. Phycol. 36 (6), 887 1119-1128.

Simkanin, C., Power, A.M., Myers, A., McGrath, D., Southward, A., Mieszkowska, N., Leaper, 889 R. O'Riordan, R, 2005. Using historical data to detect temporal changes in the abun- 890 dances of intertidal species on Irish shores. J. Mar. Biol. Assoc. U. K. 85 (06), 891 1329-1340.

Sinha, R.P., Häder, D.-P., 2002. UV-induced DNA damage and repair: a review. Photochem. 893 Photobiol. Sci. 1 (4), 225-236.

Smith, S.V., 1981. Marine macrophytes as a global carbon sink. Science 211 (4484), 895 838-840.

Starr, R.C., Zeikus, J.A., 1993. Utex - the culture collection of algae at the university of 897 Texas at Austin 1993 list of cultures. J. Phycol. 29 (2), 1-106. 898

Stauffer, M.E., Chazin, W.J., 2004. Physical interaction between replication protein A and 899 Rad51 promotes exchange on single-stranded DNA. J. Biol. Chem. 279 (24), 900 $25638-25645$.

Titiz, O., Tambasco-Studart, M., Warzych, E., Apel, K., Amrhein, N., Laloi, C., Fitzpatrick, T.B., 902 2006. PDX1 is essential for vitamin $B_{6}$ biosynthesis, development and stress tolerance 903 in Arabidopsis. Plant J. 48 (6), 933-946.

van De Poll, W., Eggert, A., Buma, A., Breeman, A., 2001. Effects of UV-B-induced DNA 905 damage and photoinhibition on growth of temperate marine red macrophytes: 906 habitat-related differences in UV-B tolerance. J. Phycol. 37 (1), 30-37. 907

van De Poll, W., Eggert, A., Buma, A., Breeman, A., 2002. Temperature dependence of UV 908 radiation effects in Arctic and temperate isolates of three red macrophytes. Eur. 909 J. Phycol. 37 (1), 59-68.

van de Poll, W., Hanelt, D. Hoyer, K., Buma, A., Breeman, A, 2003. Patterns in Ultraviolet 911 Radiation Sensitivity of Tropical, Temperate and Arctic Marine Macroalgae. 912 Rijksuniversiteit Groningen, Groningen.

Vass, I., Szilárd, A., Sicora, C., 2005. Adverse effects of UV-B light on the structure and func- 914 tion of the photosynthetic apparatus. In: Pessarakli, M. (Ed.), Handbook of 915 Photosynthesis.

Wernberg, T., Thomsen, M.S., Tuya, F., Kendrick, G.A., Staehr, P.A., Toohey, B.D., 2010. De- 917 creasing resilience of kelp beds along a latitudinal temperature gradient: potential 918 implications for a warmer future. Ecol. Lett. 13 (6), 685-694.

Wiencke, C., Lüder, U., Roleda, M., 2007. Impact of ultraviolet radiation on physiology and 920 development of zoospores of the brown alga Alaria esculenta from Spitsbergen. Phys- 921 iol. Plant. 130 (4), 601-612.

Wiencke, C., Roleda, M.Y., Gruber, A., Clayton, M.N., Bischof, K., 2006. Susceptibility of zoo- 923 spores to UV radiation determines upper depth distribution limit of Arctic kelps: ev- 924 idence through field experiments. J. Ecol. 94 (2), 455-463.

WMO, 2006. Scientific assessment of ozone depletion: 2006. Global Ozone Research and 926 Monitoring Project-Report No. 50, Geneva, p. 572.

Wold, M.S., 1997. Replication protein A: a heterotrimeric, single-stranded DNA-binding 928 protein required for eukaryotic DNA metabolism. Annu. Rev. Biochem. 66, 61-92. 929

Zhu, S.H., Green, B.R., 2010. Photoprotection in the diatom Thalassiosira pseudonana: role 930 of LI818-like proteins in response to high light stress. Biochim. Biophys. Acta, 931 Bioenerg. 1797 (8), 1449-1457. 